

\section{Shirkah}

Journal of Economics and Business

Vol. 2, No. 1, January-April 2017

ISSN: 2503-4235 (p); 2503-4243 (e)

\section{Editor in Chief}

Sri Walyoto

\section{Editorial Boards}

Abu Umar Faruq Ahmad, UBD School of Business and Economics, Brunei Darussalam

Amelia Fauzia,

Asia Research Institute, National University of Singapore, Singapore

Cedomir Nestorovic,

ESSEC Business School Asia Pacific, Singapore

Dwi Condro Triono,

Faculty of Islamic Economics and Business, IAIN Surakarta, Indonesia

Fahmy Radhi,

Faculty of Economics and Business Universitas Gadjah Mada, Yogyakarta,

Indonesia

Hasan Basri,

Syiah Kuala University, Aceh, Indonesia

Johan Fischer,

Department of Social Sciences and Business Roskilde University, Denmark

Masudul Alam Choudhury,

Postgraduate Program in Islamic Economics and Finance, Trisakti University,

Jakarta, Indonesia and the College of Economics and Political Science (CEPS) in

Sultan Qaboos University (SQU), Oman

M. Falik Isbah,

School of Humanities and Social Science, University of New South Wales, Australia M. Ishaq Bhatti,

La Trobe Business School Department of Economics and Finance La Trobe

University, Australia

Najib Kailani,

Pascasarjana, Universitas Islam Negeri (UIN) Sunan Kalijaga, Yogyakarta, Indonesia 
Nunung Nurul Hidayah,

Aston Business School, Aston University, Birmingham, United Kingdom

Shaikh M Ghazanfar,

Departement of Economics, University of Idaho, Russian Federation

\section{Managing Editors}

Fitri Wulandari

Jasanta Perangin-angin

\section{Assistant to Editor}

M. Endy Saputro

M. Zainal Anwar

Supriyanto

Shirkah Journal of Economics and Business is a peer-reviewed journal published three times a year (January-April, May-August and September-December) by Faculty of Islamic Economics and Business, Institut Agama Islam Negeri (IAIN/ State Institute for Islamic Studies) Surakarta Central Java, Indonesia. The main objective of Shirkah is to offer an academic space of exchange ideas and initiate the increase number of qualified article produced by postgraduate students, practitioners and academicians.

\section{Editorial Office}

Ruang Jurnal Shirkah

Ground Floor, West Gate,

Faculty of Islamic Economics and Business

IAIN Surakarta

Jln. Pandawa No. 1, Kartasura, Sukoharjo, Jawa Tengah Kode Pos. 57168

Phone (+62271) 781516 Fax: (+62271)782336

E-mail: shirkahiainsurakarta@gmail.com

Website: http://shirkah.or.id/ 



\section{Shirkah}

Journal of Economics and Business

Vol. 2, No. 1, January-April 2017

ISSN: 2503-4235 (p); 2503-4243 (e)

\section{Table of Contents}

\section{Articles}

Ana Zahrotun Nihayah

Savings and Loans Program, The Revenue of Small Micro Entreprises and Poverty Reduction among Women Groups

Ana Fadhilah

Muslimah Entrepreneurship and Economic Empowerment in Pengajian

Umiyati

Local Economics Empowerment and Sharia Microfinance in Rural

Community Perception

Lathif Hanarif Rifqi

Community Empowerment through Islamic Microfinances Perceptions in Comparison

Ahmad Lukman Nugraha

Islamic Business Ethics and Islamic Microfinance in Pesantren Gontor

Nova Ch. Mamuaya

Service Quality and Non-Muslim Satisfaction Using Sharia Bank Products and Services 



\title{
Islamic Business Ethics and Islamic Microfinance in Pesantren Gontor
}

\author{
Ahmad Lukman Nugraha \\ Universitas Darussalam (UNIDA) Gontor \\ ahmad.lukman.n@mail.ugm.ac.id
}

\begin{abstract}
Islam affirms that there stand for mutual affect in business processes, until the business practice as a work field recommended to the adherents; while discussing ethics of business activity poped out to minimize cheating and fraud activities. However, Islamic business ethics felt difficult to apply in practice, especially in the business of buying and selling. Modern Islamic Boarding School "Darussalam" Gontor is one of the self-financing and self-help islamic boarding schools in the economic supported by cooperatives in pesantren (koppontren). This paper aims to comprehensively understand the application of Islamic business ethics and focus on the entrepreneurs in business sectors Gontor LaTansa's cooperatives. This research had systematically employed mix method research with sequential explanatory design and case study. Gathering data through using questionnaires, interviews, observation and documentation has been performing analysis through data reduction, data display, and data verification. This paper argues that Gontor La-Tansa's cooperatives sector can run the business activities with implementing business ethics according to the Qur'an and Sunna values. Appear from the height comprehension of the business to the axiom business ethics and the height application in business activities in each business sector. In addition, the role of kiai and business unit supervisor is high. Data displays a level of the height direction (80 percent) and control on the application of business ethics ( 72 percent). The Islamic business ethics can be applied on firm's and government's law with height comprehension and controlling.
\end{abstract}

Keyword: Islamic business ethics, Gontor, pesantren, kiai

\section{Introduction}

Ethics is often paired up with morality. Keraf (1998) distinguished these two are first, ethics is derived from the word ethos meaning custom or 
habit with similarity between ethics and moral. Moral is derived from the word mos. The meaning is similar to ethos custom or habit. In other word, ethics and moral have similar meaning namely custom or habit relate to values, good life regulation. The regulation is followed by one person and another. Second, ethics is the knowledge concludes from moral philosophy (Keraf, 1998: 13-15). According to Kamus Besar bahasa Indonesia (KBBI) there are three things to explain ethics: knowledge explaining good and bad, and also on rights and obligation; the collection of principles or values relates to akhlaq; and the value of right or wrong followed by a group of people (Badan Pembinaan dan Pengembangan Bahasa, 2015). In addition, Magnis-Suseno (1987: 14) considers ethics as knowledge not teaching, distinguished ethics and moral from its definition and function.

Ethics in philosophy is studying value and moral with critical and rational study. Magnis-Suseno (1987: 23) said there are deontology ethics and theology ethics. The former ethics is focusing on human obligation to act well, not confirmed by the cause or goal but by the act itself. In contrary, the theology ethics measured an action good or bad from the caused or the purpose of the act. Take for an example of stealing, in deontology ethics it is considered bad due to the act taking other people rights. However, the theology ethics will foresee the caused and goal. Why is he stealing? For what is he stealing? Whereas the goal of the stealing is good therefore the stealing is a good act.

Ethics has basic similarity with moral and akhlaq, due to the three studies on human behavior, good and bad norm, also the right and the wrong (Kalemci and Kalemci, 2017). All of the three are wanting good, secure, tidy, peaceful, save and comfortable condition for the community (Nata, 2010: 97). The difference of those three is located on guidance source to determine the good and bad; and also the discussion. The ethics determines good or bad base on thought and logic; and also on ethical 
discussion on people behavior in general. The moral determines good and bad base on the group's habit and the discussion is on the individual behavior. The akhlaq determines good and bad base on the Qur'an and Hadith. The discussion is managing the individual and people behavior (Abdelzaher, 2017).

Business is organized social process conducted by individual or group to produce and sell products in fulfilling several community needs (Kismono, 2001: 4). It is considered business as community activity to enhance the additional value with the process of service handover, trading or goods processing. Yusanto and Wijayakusuma (2002: 11) stated that business as goods, services, and money barter with profited all parties and providing utility. Meanwhile, Islam provides values as basic for every effort of its follower to live. Al-Qur'an and Sunna are the basic for values and ethics of people life including the regulation on business ethics. Naqvi (1981: 64) said economic and business activities are being regulated in the Qur'an and Sunna. Business in al-Qur'an is called tijarah and bai' meaning goods or services barter. Business activities are permitted in the Qur'an and exemplified by Rasulullah. Allah says on an-Nisa': 29

O ye who believe! Eat not up your property among yourself in vanities, but let there among you traffic and trade, by mutual good-will, nor kill (or destroy) yourselves. For verily God hath been for you most Merciful (QS. an-Nisa'(4): 29).

The verse explains transaction (eat up your property among yourself) legalized by the Qur'an namely business (trading) and the permitted trade is the one profited all parties and the practice is based on justice. Therefore business practice has been allowed in Islam with provision of trading goods achievement and empowerment (Muhammad, 2004: 37). Business activities legalization is supported with Rasulullah in history: 
Narrated by Ali, a man came to meet with Rasulullah asking about the better effort (finding rizq). Rasulullah said, "A man works with his hands and every trading transaction is permitted. Allah actually likes professional faithful person and person who suffers to support his family, they similar with fighters in Allah's way" (HR. Muttafaq 'alaih).

The hadith endorses the best effort to find wealth is with his/ her own hands without begging from other people and permitted trading transaction (business). This hadith strongly emphasizes and supports previous Qur'an verse on trading (business) practice legality as recommendation exemplified by Muhammad.

Business world in this modern era is inseparable from speculation, fraud, prohibited things, and gambling diverging from ethical norms and religions. Many business operators stated business world does not need religiosity but needing professionalism (Arli and Tjiptono, 2017). Business and ethics are considered having opposites position and not at all related. Business practice is considered as an activity to gain the biggest profit with strict competition legalizing any ways to achieve the goal. The ethics or moral however is full of values and norms binding its operators. Muhammad (2014: 15) said there will be dilemma whereas ethics is applied in business world. Business is considered as amoral activity, not uncomplimentary and should be avoided.

Business is the activity to enhance additional with service delivery, trading, or good processing (Keraf, 1998: 23). Yusanto and Wijayakusuma (2002: 11) said business is the barter of goods, services or money profiting and providing usefulness to all parties. Kismono (2001:4) defines business as organized social process conducted by individual or group to produce and fulfilling several communities' needs. It means business is the activity conducted by human to gain profit and fulfilling community's needs. 
The business purpose is not only to fulfill community's need, it is also able to interest consumer to buy and maintaining the business operation. Kismono (2001: 15) said several factors are related to business world, namely: needs fulfillment and consumer demand, business profit, sustainable development and growth, solving various risk, and social responsibility. Business profit would be an important factor due to this factor ability to maintain and develop business activities.

The profit maximizing effort as the business goal providing opportunity to create incorrect business attitudes and moral crises endangering many parties, such as using less qualified production materials, subtracting total quantity and marketing not in accordance with production result. Meliala (1993: 27-28) said the deviation is unfair business practice such as fraud, steal, tampering, cheating, scheming, authority misconduct, oppression, blackmailing the weak, and harming other people. This condition needs ethics role to encounter critical moral business attitudes. Islam however is managing business with fiqh muamalat norm to achieve akhlaq as the attitude goal in economics and business.

The merging ethics and business means forcing religious norms on business world, putting business profession ethics code, revising the system and economics law; therefore business ethics is only circulated in academics world (Kamri, 2017). Applied ethical theories were introduced to university students who learn it. The business ethics will change from time to time in accordance with technology and community cultural development (Svensson and Wood, 2003).

Ethical business exemplified by Prophet Muhammad since 1,400 years ago. Many of prophet Muhammad ethical behaviors have been applied by the santri as the result of Islamic boarding house education result. Islamic boarding house has continuously been religious education institution with 
characteristics of simplicity, trustable, social, and hard working. Kiai as motivator and teacher has an obligatory to support his students to live independently in economics and social community (Zarkasyi, 2011: 22). Therefore, Islamic boarding school as an education institution supposed to be have independent economic system (self-funding and self-assisting) to develop various business activities following ethical norms.

The research questions are formulated to focus on the purpose corridor. Several problems of the research intended to address such question on the business ethics of the Qur'an and Hadith applied the LaTansa Koppontren Darussalam Modern Islam Boarding House Gontor and the role of kiai in teaching and supervising business units' operator in applying business ethics at the Islam boarding school cooperation. This research was using mixed method approach. Mixed method is a research approach combining quantitative and qualitative method. The research methods with this design's characters are the first stage is data collecting and quantitative analysis; and the second stage is data collecting and qualitative data analysis to support the research result (Sugiyono, 2012: 409).

The most independent qualitative data collecting technique on data collecting methods are questionnaire method, in-depth interview, participation observation, and documentary materials. The data source in this research is the Modern Islamic Boarding School Darussalam Gontors' teachers as Koppotren business unit operators. The other data source is its leader, the director of modern Islamic boarding school expansion and maintenance foundation, its vice director, its treasurer, its administration staff, and its business unit advisor as observer and referrer.

\section{Business Ethics Axiom}

The debate on business ethics has emerged in 1960s. The discussion of ethical philosophy was starting to open for actual aspects (Bertens, 
1994: 12). Discussion on philosophical object has created "applied ethics" for various fields. Business ethics is one of the applied ethics born at USA in 1970's and expanding to Europe in 1980's (Wijaya and Noor, 2013: 20). Business ethical issue was a global phenomenon in 1990's. Moral in business previously was only talked by theologians and religious figures. Several philosophers, afterwards was starting to involve in business ethics discussion.

Business ethics was considered significance to study after amoral business myth (George, 1986: 3-5). Business was considered as an activity far from or even excluded from moral. Business, in fact, is activity motivated by profit and denying moral in its application. According to Keraf (1998: 56-58) business offers gambling game allowing all ways to earn profit. Business is competition focusing on personal need. The regulation used in business is various. Ethics follower business operator is at disadvantageous position on business world strict competition. Business and ethics are considered as two opposites matters.

The amoral business myth creates discussion whereas long term business vision denying business similarity with gambling. Business is often considered similar with gambling due to its strict competition. Even though in business the operator was gambling himself, his name, his family, his and his family whole life, and also his community need (Khan, 2017). The explaining statement on business has various regulation is incorrect; it is due to business activities' significance in the community. Therefore community will be automatically creating regulation and business operators refuse to follow it will automatically eliminated. This is also happening to the business operators following ethics and moral, they will survive with community as permanent customer (Keraf, 1998: 60-61). 
The researcher found many discussions explaining business ethics axiom. Keraf (1998: 73-81) explained business ethics five principles discovering from classical ethics philosophy: (a) autonomy principle; (b) honesty principle; (c) justice principle; (d) mutual benefit principle; (e) moral integrity principle. However, Naqvi (1987: 75) said there are four principles in business ethics written in the Qur'an and Hadith namely: (a) Tauhid; (b) 'Adl; (c) Free will, and (d) Responsibility. In accordance with Naqvi, Beekun (1997) was explaining business ethics principles with adding ihsan (e) benevolence principle as business activity utility. Zarkasy (2003) explained that the business ethics axiom in seven matters, namely: (a) ibadah, (b) khilafah, (c) 'adalah, (d) shiddiq, (e) amanah, (f) ta'awun, (g) ibsan.

The main theoretical framework on ethics here would be merging business ethics axiom from several leading figures such as Keraf (1998) and Zarkasy (2003). This is the result of leading figures thought: (a) worshiping principle as application of tauhid principle with Allah unity due to belief whereas all human activities are the embodiment of God worshipping; (b) khilafah principle as the expansion of autonomy principle providing freedom to the business operator in determining policy as the embodiment of freewill; and human relation with amanah (responsibility) on every action; (c) shiddiq principle as nubuwwah nature and honesty interpretation in business perspective (Keraf, 1998); (d) 'adalah principle is the xpansion of distribution balance and determining price justice for producer and consumer; (e) ta'awun principle is the embodiment of business activities as social process to fulfill community needs and mutual benefit in community activities; and (f) ihsan principle is similar with moral integrity supporting business operator to conduct the best in business activities. 


\section{La Tansa Business Ethics}

Koppontren refers to cooperation with members from similar group, namely the family member of Islamic boarding house such as kiai, teacher, and students (Baswir, 2010: 30). Koperasi derived from English, cooperation, meaning working together. Therefore any kind of working together may consider as cooperation. Cooperation in this term is not any job solving together in general, the cooperation meaning here is the company established by certain people to conduct certain actions, base on certain provision, for certain goal (Reksohadiprojo, 1998: 1-2). Hatta (1954: 2) defined cooperation as the weaklings group to defend their life's needs, achieve the life's need with the cheapest cost. Cooperation is focusing on common needs not profit. According to Cooperation Law No. 121967 the cooperation main principles are:

Indonesia Cooperation is community economic organization with social nature, consists of people or cooperation legal entities as economic arrangement base on family principle.

There are three cooperation foundation and principles (Anaraga and Widayanti, 1993: 8-9): (1) Indonesia cooperation ideal foundation, the foundation describes life perspective and the state moral aim achievement. Indonesia ideal foundation is Pancasila; (2) Indonesia cooperation structural foundation. All provisions or basic regulation is regulating the nation philosophy, 1945 Constitution, as soul and national moral aim to be internalized and practiced. The 1945 Constitution is managing economics activities arranged as the foundation of working together with family principle (UUD, 1945, article 33, verse 1); (3) Cooperation mental foundation. This foundation explains the existence of desire and passion to live; focusing on helping each other among human base on moral level and integrity, solidarity and individual awareness as personal creature to socialize and working with other people. 
According to Law No. 251992 cooperation principles are (Hatasushu, 2001: 2; Reksohadiprojo, 1997: 2); (1) membership is voluntary and open; (2) Democratic management; (3) The surplus is divided equally depending on the member portion; (4) recompense is not relate to modal deposit amount; (5) Independence; (6) Cooperation education; (7) Cooperation among the cooperation. Modern Islamic Boarding School Darussalam has 31 business units incorporated in Koppotren La Tansa Gontor (Dokumentasi, 2014). It was established since 1970, consisted of books store, construction material store, photocopy, pharmacy, rice mill, cattle farm, guest house, and computer reparation managed by the teachers. The teachers teach the students, they are mandated as business operator and administrator in administrative or operative term (Dokumentasi, 2009). The business unit at this school is not merely gaining economical profit in supporting the school need, it is also used as worshipping and training facility for the business operator incorporated of Koppotren La Tansa Gontor.

Modern Islamic Boarding School Darussalam Gontor as selffunding and self-managed school, meaning the school funding and management is not depended on other parties. Therefore there is a slogan "by santri from santri and for santri" (Zarkasyi, 2005: 186-196). The school was then creating business units to establish to be managed by the teachers and students. The outcome is used to support education and learning process, and also manifestation five terms, namely khizanatullah/ funding. The wealth fulfillment at this school is not paid by the students with monthly payment. La Tansa Koppontren in 1970-2015 has developed 31 (thirty one) business units (Laporan, 2014). Researcher was focusing on business units distributing aspect or business unit buying and selling things. The distributing aspect business units are: La Tansa book store, Palen Store, Iron Store, La Tansa Drugstore, Wholesale, Al Azhar Cafetaria, Asia Photocopy, Grocery Store, Sport Tools Store, and UKK Mini Market. 
The La Tansa Koppontren business operator is the servitude teacher. La Tansa Koppontren other functions than business sector is business education facility for the teacher. Teachers in this school has three functions namely educator, university student; and also school and society servitude (business unit operator). The business operators are taught to manage business and creating profit. The Koppontren business operators are unmarried. Senior teachers have function as advisor and supervisor the business operation without involving in financial matter (Interview with Imam Muchtar, 2015). Senior teacher is Gontor teacher who has spent most of his/ her life on work and married. Every business unit has advisor to supervise the work and direct the business activity of the business operators. The respondents' data explained by researcher below:

Table 1

\section{Respondent Comprehension on Business Ethics}

\begin{tabular}{|c|l|c|c|c|c|c|}
\hline No. & \multicolumn{1}{|c|}{ Axiom } & $\mathbf{1}$ & $\mathbf{2}$ & $\mathbf{3}$ & $\mathbf{4}$ & $\mathbf{5}$ \\
\hline 1 & Ibadah Principle & 0 & 1 & 9 & 38 & 52 \\
\hline 2 & Khilafah Principle & 0 & 4 & 22 & 47 & 27 \\
\hline 3 & Shiddiq Principle & 0 & 1 & 15 & 51 & 33 \\
\hline 4 & Adalah Principle & 0 & 3 & 22 & 48 & 26 \\
\hline 5 & Táawun Principle & 0 & 2 & 22 & 47 & 29 \\
\hline 6 & Ihsan Principle & 1 & 5 & 20 & 53 & 21 \\
\hline \multicolumn{2}{|c|}{ Average values } & 0,16 & 2,66 & 18,33 & 47,33 & 31,33 \\
\hline
\end{tabular}

The data show the business ethics comprehension level from every high axiom. $78.88 \%$ of the respondents understand the business ethics explanation from previous statement. The data also show business operators understand the ethical norms, with need of enhancement business ethics theory comprehension. The business practice at La Tansa Koppontren operated more to practice than to theoretical ethics axiom comprehension due to the Islamic Boarding School does not create professional business operator, yet using ethics as the basic of all activities in society. The school 
conducts this due to its function as regeneration institution (interview with Hasib Amrullah, 2015).

La Tansa Koppontren business operators have high comprehension on business ethics axiom content. The business operator comprehension on business ethics is with high intension direction and supervision. The La Tansa Koppontren business operators understand every business ethics principles. The school gives some training to the business operator and implants Islamic ethics. The students will be able to apply ethical norm in society.

Table 2

Respondent Ethical Business Application Level

\begin{tabular}{|c|l|c|c|c|c|c|}
\hline No. & \multicolumn{1}{|c|}{ Axiom } & $\mathbf{1}$ & $\mathbf{2}$ & $\mathbf{3}$ & $\mathbf{4}$ & $\mathbf{5}$ \\
\hline 1 & Ibadah Principle & 0 & 4 & 36 & 39 & 21 \\
\hline 2 & Khilafah Principle & 0 & 4 & 38 & 41 & 18 \\
\hline 3 & Shiddiq Principle & 0 & 2 & 16 & 45 & 38 \\
\hline 4 & Adalah Principle & 0 & 2 & 25 & 50 & 23 \\
\hline 5 & Táawun Principle & 0 & 7 & 25 & 46 & 21 \\
\hline 6 & Ihsan Principle & 0 & 4 & 13 & 64 & 20 \\
\hline \multicolumn{2}{|c|}{ Average Values } & $\mathbf{0}$ & $\mathbf{4}$ & $\mathbf{2 4}$ & $\mathbf{4 8}$ & $\mathbf{2 4}$ \\
\hline
\end{tabular}

The respondents answers show data of principles application level in business ethics in whole is high, with $72 \%$ of respondents. High ethical business application at La Tansa Koppontren is supported by intense supervising of the School Headmaster, YPPWPM director, Treasurer, and senior teachers as advisor. The function of advisors is not only supervising monthly report and performance, they are supposed to directly involved and following the business operator activities. The La Tansa Koppontren business operator will be felt motivated and supervised in every activity. The business ethics application is supported by supervising factor and high comprehension on school values. The school values are becoming norms 
and life guidance for the people living inside it. The business operator's comprehension on high Islamic boarding school values is inseparable from the guidance of School headmaster, YPPWPM director, and the business unit advisor. The significant guidance has directly affected business ethics application at La Tansa Koppontren.

Table 3

Respondent Business Ethics Direction Level

\begin{tabular}{|c|l|c|c|c|c|c|}
\hline No. & \multicolumn{1}{|c|}{ Axiom } & $\mathbf{1}$ & $\mathbf{2}$ & $\mathbf{3}$ & $\mathbf{4}$ & $\mathbf{5}$ \\
\hline 1 & Ibadah Principle & 0 & 0 & 18 & 36 & 46 \\
\hline 2 & Khilafah Principle & 2 & 2 & 25 & 36 & 36 \\
\hline 3 & Shiddiq Principle & 0 & 0 & 16 & 38 & 46 \\
\hline 4 & Adalah Principle & 0 & 2 & 16 & 46 & 36 \\
\hline 5 & Táawun Principle & 0 & 4 & 20 & 45 & 32 \\
\hline 6 & Ihsan Principle & 0 & 4 & 13 & 52 & 32 \\
\hline \multicolumn{2}{|c|}{ Average Values } & $\mathbf{0}$ & $\mathbf{2}$ & $\mathbf{1 8}$ & $\mathbf{4 2}$ & $\mathbf{3 8}$ \\
\hline
\end{tabular}

The respondents answer show the business ethics principles direction level measurement in whole is high with $80 \%$ of the respondents. The direction indicator is the highest among other indicators. Islamic boarding school is the institution with close membership relation. Therefore the direction is not only in formal but also informal. The formal form is the kiai and YPPWPM director's direction on meeting annually, monthly, and three-monthly at the same time as business unit report. The informal direction is the kiai and business advisor direction conducted every day. The school headmaster supervises each business unit operator in rotation and giving direction face to face. The direction intensity is expected used as the observation for business operators. 
Table 4

Respondent Business Ethics Supervising Level

\begin{tabular}{|c|l|c|c|c|c|c|}
\hline No. & \multicolumn{1}{|c|}{ Axiom } & $\mathbf{1}$ & $\mathbf{2}$ & $\mathbf{3}$ & $\mathbf{4}$ & $\mathbf{5}$ \\
\hline 1 & Ibadah Principle & 0 & 4 & 29 & 39 & 29 \\
\hline 2 & Khilafah Principle & 0 & 4 & 30 & 39 & 27 \\
\hline 3 & Shiddiq Principle & 0 & 4 & 23 & 36 & 38 \\
\hline 4 & Adalah Principle & 0 & 2 & 25 & 46 & 27 \\
\hline 5 & Táawun Principle & 0 & 4 & 25 & 43 & 29 \\
\hline 6 & Ihsan Principle & 0 & 4 & 16 & 54 & 27 \\
\hline \multicolumn{2}{|c|}{ Average values } & $\mathbf{0}$ & $\mathbf{3}$ & $\mathbf{2 5}$ & $\mathbf{4 3}$ & $\mathbf{2 9}$ \\
\hline
\end{tabular}

The respondents answer show the business ethics principles supervision level measurement in whole is high with $72 \%$ of the respondents. There are three levels of supervision at La Tansa Koppontren: (a) seniority; (b) guidance; and (c) leadership. The first supervision position is on the business operator seniority. Senior business operators have obligation to supervise and assist the junior at every business ethics activities. The second level is held by supervisor. This supervision is conducted everyday incidentally and structurally every week. The structural supervisions for example are monthly report and weekly meeting. The third level is held by the school headmaster and YPPWPM director. This supervision is more structurally than incidentally. The incidental supervision is conducted in rotation, made the business operator motivated and supervised on every business activities.

\section{Kiai and Business Operator Role}

Collecting the business ethics axiom average data from previous data consists of the level of comprehension, application, direction and supervision. 


\section{Table 5}

Respondent Evaluation on Business Ethics Indicators (percentage)

\begin{tabular}{|c|l|c|c|c|c|}
\hline No. & Axiom & Comprehension & Application & Direction & Observation \\
\hline 1 & Ibadah Principle & 90 & 60 & 82 & 68 \\
\hline 2 & Khilafah Principle & 74 & 59 & 72 & 66 \\
\hline 3 & Shiddiq Principle & 84 & 83 & 84 & 74 \\
\hline 4 & Adalah Principle & 74 & 73 & 82 & 73 \\
\hline 5 & Táawun Principle & 76 & 67 & 77 & 72 \\
\hline 6 & Ihsan Principle & 74 & 84 & 84 & 81 \\
\hline \multicolumn{2}{|c|}{ Average Values } & $\mathbf{7 8 , 6 6}$ & $\mathbf{7 2}$ & $\mathbf{8 0}$ & $\mathbf{7 2}$ \\
\hline
\end{tabular}

The data show the average respondent comprehension level on business ethics is 78.66. The average on business ethics application level at La Tansa Koppontren is 72 . The average on business ethics direction level at La Tansa Koppontren is 80 . The average on business ethics supervision level at La Tansa Koppontren is 72 . The data shows respondent comprehension on business ethics level (78.66) is affected by direction level (80). The business ethics application level at La Tansa Koppontren (72) is affected by supervision level (71). The data show respondent evaluation levels from the highest to the lowest value are: direction (80), comprehension (78.66), supervision (72), and application (72).

Islamic boarding school is the oldest education institution in Indonesia in Islamic learning, studying, internalizing, and practicing. This institution is focusing on the religious moral significance as daily guidance to develop Muslim personality (Mastuhu, 1994: 55). The Islamic boarding school is lead by kiai as central figure of every activities and decision maker. Mastuhu (1994: 126) said that kiai has a role of maintaining religious values in the institution. Therefore, the institution achievement and student's credibility is inseparable from kiai role as teacher with adhering doctrine while studying at Islamic boarding school. The alumni 
was bringing doctrine and teaching taught by the kiai and teachers to be practiced in their society. The Islamic boarding school review shows it is a place to educate community leaders, entering in various studies such as teacher, government bureaucrat and others.

The Modern Islamic Boarding School Darussalam is one of the oldest Islamic boarding schools in Indonesia. It was established in 1926 with the goal preparing excellent generation though various trainings. At 90 years active operation, the school is still able to maintain its vision and mission. One regeneration method in used is training and assignment (Zarkasyi, 2001: 28-32). The students and the teachers are early trained to be responsible. Senior students are assigned to sustain the cafeteria, cooperation, junior students in the boarding house, and organization as the embodiment of dedication to the school and training facilities as provision in society. The student training in this school is not merely given tasks; there is also briefing as skill and meaning provision in every activity.

The conclusion is business ethics' application in business sector needs strong direction for the business operator and made them understand clearly. Business operator comprehension on business ethics axiom is without complete business ethics application. High comprehension does not usually establish high application, it will need strict supervision. The data show that kiai and senior teachers as Gontor La Tansa Koppontren business unit advisor have significant role in business ethics application as supervisor and director. The school headmaster and YPPWPM Director's supervision and direction affect the business ethics comprehension and application at the La Tansa Kopponten.

\section{Conclusion}

Business ethics mentioning in the Qur'an and Hadith has been well applied at the Modern Islamic Boarding School La Tansa Koppontren. 
It shows on the high level of business ethics axiom application and comprehension at La Tansa Koppontren. The data show business ethics comprehension level is $78.66 \%$ and the business ethics application level is $72 \%$. The business ethics application at Gontor La Tansa Koppontren is supported with Islamic school values believed by its every business operator. Business operator's worshipping and ihsan application tenacity is the embodiment of God calling in business activities. The business operator at La Tansa Koopontren comprehension khilafah (autonomy) principle needs enhancement. The autonomy application in the line of business made the business operator to be more innovative. The Modern Islamic Boarding School conducts structural autonomy combining individual autonomy and guided autonomy. The enhancement of khilafah principle comprehension is conducted with business training and comparative study to prominent business sectors. It will make the business operator to be more innovative and support the La Tansa Koppontren development in the long term.

The role of kiai and business unit advisor to teach and supervise business ethics application of La Tansa Koppontren business operator reaches in high level. The data show the business ethics direction level is $80 \%$ and business ethics supervision level is $72 \%$. The school headmaster and the YPPWPM Director's direction and supervision are affecting the business ethics comprehension and application at La Tansa Koppontren. The kiai and advisor have significant role on business ethics application's direction and supervision at La Tansa Koppontren. It needs supervision process enhancement therefore the complete business ethics application at La Tansa Koppontren to balance the supervision and direction level. The enhancement of direction process on business operator is conducted with adding advisor quantity to supervise every business unit. It is due to high direction will need strict supervision. The business ethics direction level 
will affect the business operator comprehension, whereas supervision level will affect high business ethics activities and in the end will affect business ethics axiom application of the business operator every activity.

\section{References}

Abdelzaher, D.M, Kotb, A., Helfaya, A. (2017). Eco Islam: Beyond the Principles of Why and What, and Into the Principles of How. Journal of Business Ethics, pp. 1-21.

An Nabhani, T. (2009). Membangun Sistem Ekonomi Alternatif Perspektif Islam. Diterjemahkan oleh Maghfur Wachid. Surabaya: Risalah Gusti. Anoraga, P dan W. N. (1993). Dinamika Koperasi. Jakarta: Rineka Cipta. Arli, D., Tjiptono, F. (2017). God and Green: Investigating The Impact of Religiousness on Green Marketing. International Journal of Nonprofit and Voluntary Sector Marketing 22 (3), e1578.

Badan Pengembangan dan Pembinaan Bahasa. (2015). "Kamus Besar Bahasa Indonesia”, http://kbbi.web.id/ etika, diakses pada tanggal 13 Juni 2015.

Baswir, R. (2010). Koperasi Indonesia. Yogyakarta: BPFE UGM.

Bungin, M. B. (2007). Penelitian Kualitatif Komunikasi, Ekonomi, Kebijakan Publik dan Ilmu Sosial Lainnya, Jakarta: Kencana.

Bungin, M.B. (2013). Metodologi Penelitian Sosial dan Ekonomi: Formatformat Kuantitatif dan Kualitatif untuk Studi Sosiologi, Kebijakan Publik, Komunikasi, Manajemen dan Pemasaran. Jakarta: Kencana.

Burhanuddin, H. (2013). "Etika Bisnis Menurut Islam (Suatu telaah material-Immaterial oriented)", dalam Etika Ekonomi dan Bisnis Perspektif Agama-agama di Indonesia, Diedit oleh Wijaya, Yahya dan Noor, Nina M., Geneva: Globethic.net. 
Beekun, R.I. (1997). Islamic Business Ethic. Virginia: International Institute of Islamic Thought.

Bertens, K. (1993). Etika. Jakarta: PT Gramedia Pustaka Utama.

Creswell, J.W. (2009). Researce Design; Qualitative, Quantitative, and Mixed Methods. Boston: McGraw-Hill.

Cresswell, J.W. (2013). Penelitian Kualitatif dan Desigh Riset: Memilih diantara Lima Pendekatan, Diterjemahkan oleh Ahmad Lintang Lazuardi, Yogyakarta: Pustaka Pelajar.

De George, R. T. (1986). Business Ethics. New York: MacMillan Publishing. Departemen Pendidikan dan Kebudayaan (1988). Kamus Besar Bahasa Indonesia (Edisi kedua). Jakarta: Depdikbud.

Dhofier, Z. (1982). Tradisi Pesantren; Studi Tentang Pandangan Hidup Kyai. Jakarta: LP3ES.

Hatta, M. (1954). Kumpulan Karangan III.Jakarta: Balai Pustaka.

Hatasuhu, A.D. (2001). "Manajemen Koperasi Menuju Kewirausaan Koperasi". Jurnal Ilmiah Manajemen dan Bisnis Universitas Muhammadiyah Sumatra, Vol.1, Oktober.

Kamri, N.A., Basir, S.A., Ramlan, S.F. (2017). Implementing Ethical Codes at Workplace: A Discussion on The Factors of The Enforcement, Employee Awareness and Understanding. Pertanika Journal of Social Sciences and Humanities 25 (2), pp. 761-781.

Kalemci, R.A., Kalemci Tuzun, I. (2017). Understanding Protestant and Islamic Work Ethic Studies: A Content Analysis of Articles. Journal of Business Ethics, pp. 1-10.

Keraf, A. S. (1998). Etika Bisnis Tuntutan dan Relevansinya.Yogyakarta: Kanisius.

Khan, M.A. (2017). Business Education Across Regions: The Case of The Middle East. Business Education and Ethics: Concept, Methodologies, Tools, and Applications 2-3, pp. 946-963.

Kismono, G. (2013). Bisnis Pengantar. Yogyakarta: BPFE-UGM. 
Latief, D. (2006). Etika Bisnis antara Norma dan Realitas. Surakarta: Muhammadiyah University Press.

Magnis-Suseno, F. (1987). Etika Dasar: Masalah-Masalah Pokok Filsafat Moral. Yogyakarta: Kanisius.

Mastuhu. (1994). Dinamika Sistem Pendidikan Pesantren; Suatu Kajian Tentang Unsur dan Nilai Sistem Pendidikan Pesantren. Jakarta: INIS.

Miskawaih, I. (1934). Tahzibu-l-Akhlaq wa Tathhiru-l-A'raq, Mesir: Al Mathba'ah Al Mishriyyah.

Miles, M dan H. M. (1992). Analisis Data Qualitatif. Diterjemahkan Tjejep Rohendi Rohidi, oleh, Jakarta: UI Press.

Moleong, L. J. (1989). Metodologi Penelitian Kualitatif, Jakarta: Remaja Rosyda Karya.

Muhadjir, N. (1989). Metodologi Penelitian Kualitatif, Yogyakarta: Rake Sasarin.

Muhammad. (2004). Etika Bisnis Islami, Yogyakarta: Pustaka Pelajar.

Naqvi, S. N. H. (1985). Etika dan Ilmu Ekonomi; Suatu Sintesis Islami, Diterjemahkan oleh Anis, Husin dan Hikmat, Asep, Bandung: Mizan.

Nata, A. (2010). Akhlak Tasawwuf. Jakarta: Rajawali Press.

Nurdin, B. dan A.Y. (1993). Beberapa Aspek Historis Perkembangan Koperasi di Indonesia, dalam Mencari Bentuk, Posisi, dan Realita Koperasi dalam Orde Ekonomi Indonesia. Diedit oleh Swasono, Sri Edi, Jakarta: UI Press.

Pals, D.L. (2006). Dekontruksi Kebenaran Kritik Tujuh Teori Agama. Diterjemahkan oleh Muzir, Inyiak Ridwan dan Syukri, M. Yogyakarta: IRCiSoD.

Reksohardjiprojo, S. (1998). Manajemen Koperasi. Edisi kelima. Yogyakarta: BPFE.

Rianto, A. (2005). Metodelogi Penelitian Sosial dan Hukum. Jakarta: Granit. Soeratno dan A. L. (2003). Metodologi Penelitian untuk Ekonomi dan Bisnis. Yogyakara: UPP-AMP YKPN. 
Sugiyono. (2010). Metode Penelitian Kuantitatif, Kualitatif dan R\&D. Bandung: Alfabeta.

Sugiyono. (2013). Metode Penelitian Kombinasi (Mixed Methods). Bandung: Alfabeta.

Streenbrink, K.A.. (1986). Pesantren Madrasah Sekolah; Pendidikan Islam dalam Kurun kurun Modern. Jakarta: LP3ES.

Svensson, G. and W. G. (2003). "The Dynamics of Business Ethics: a funcion of time and culture-case and models". Jurnal Management Decision. 41(4). 2003

Svensson, G. (2008). "A Model of Business Ethics". Jurnal of Business Ethics. 77 (3). February.2008.

Tran, B. (2008). "Paradigms in Corporate Ethics: the legality and values of corporate ethics”, Sosial Responsibility Journal. 4.(1/ 2). 2008.

Tim Penyusun. (2007). Pengelolaan Yayasan: Pengalaman Yayasan Pemeliharaan dan Perluasan WakafPondok Modern Darussalam Gontor. Ponorogo: Dokumentasi YPPWPM.

Warta Dunia Pondok Modern Darussalam Gontor. Risalah Akhir Tahun Ajaran 2009, 2012-2015, Ponorogo: Darussalam Press.

Weber, M. (2006). Etika Protestan dan Spirit Kapitalisme; Sejarah Kemunculan dan Ramalan Tentang Perkembangan Kultur Industrial Kontemporer Secara Menyeluruh (transl. Utomo, TW dan Sudiraja, Yusuf P). Yogyakarta: Pustaka Pelajar.

Yusanto dan W. (2002). Menggagas Bisnis Islami, Jakarta: Gema Insani Press.

Zarkasyi, A. S. (2003). "Etika Bisnis dalam Islam dan Relevansinya dalam Aktivitas Bisnis: Studi Kasus Pondok Modern Gontor", disampaikan pada Seminar Business Ethics and Enterpreneurship in Islamic Perspective, di Fakultas Syariah UIN Sunan Kalijaga, pada 26 Februari 2003. Yogyakarta: UIN Sunan Kalijaga 
Zarkasyi, A. S. (2011). Bekal Untuk Memimpin: Pengalaman Meminpin Gontor, Ponorogo: Trimurti Press.

Ziemek, M. (1986). Pesantren dalam Perubahan Sosial. Jakarta: Penghimpunan Pengembangan Pesantren dan Masyarakat (P3M).

Wawancara dengan ketua Yayasan Perluasan dan Pemeliharaan Wakaf Pondok Modern Darussalam Gontor Ustadz H. Imam Shobari, S.Ag., di kantor YPPWPM gedung Asia, Pada tanggal 3 Mei 2015.

Wawancara dengan wakil Ketua Yayasan Perluasan dan Pemeliharaan Wakaf Pondok Modern Darussalam Gontor Ustadz Drs. H. Imam Muchtar., di kantor YPPWPM gedung Asia, May 3, 2015.

Wawancara dengan Bendahara Yayasan Perluasan dan Pemeliharaan Wakaf Pondok Modern Darussalam Gontor Ustadz Suraji Badi', S.Ag., di rumah wisma Darussalam, May 5, 2015.

Wawancara dengan Pembimbing Koppontren "La-Tansa" Unit KUK Ustadz Hasib Amrullah, M.Ud., di rumah Baitu-l-Makkah, May 7, 2015 .

Wawancara dengan staff Administrasi Pondok Modern Darussalam Gontor Ustadz Zaein Nasruddin Fajri, S.H.I, di kantor Administrasi gedung Madrasah, May 8, 2015. 


\section{Shirkah Author Guidelines}

Shirkah currently offers two routes to submit manuscripts. We highly recommend to submit the articles which are made using OJS (Open Journal System). Feel free register as author soon through visiting http:// shirkah.or.id/index.php/home/user/register. The authors may directly send their manuscripts, along with their resume, to shirkahiainsurakarta@ gmail.com. Please prepare your manuscripts, using following guidelines:

1. Manuscript must be written in English. Submitted articles should not have been published or be under review for publication with another journal.

2. Manuscript's length is about $15-20$ pages, typed in one-half spaced on A4-paper size.

3. Manuscript must include an $150-200$ word abstract and keywords.

4. Manuscript must be arranged as follows: Title, Name of Author, E-mail address, Abstract, Keywords, Introduction (including method if any), Discussion, Conclusion, References.

5. Manuscript's titles not more than ten words.

6. Manuscript must be submitted in Microsoft Word or RTF.

7. Arabic words should be transliterated according to the style of International Journal of Middle Eastern Studies.

8. Manuscript references are preferably derived from the up-to-date references.

9. The author's resume should be submitted separately, consisting of at least full name, institutional address, phone number, areas of studies, and recent publications (if any).

10. Shirkab use APA Style 6th edition (2010) as reference format writing. We suggest the use of a reference manager software such as Mendeley, Zotero, and Endnote at templating the citation style. APA Style to be used is as follows: 


\section{Book with single author}

Swann, G. M. Peter. (2014). The Economics of Innovation an Introduction. Cheltenhum \& Northampton: Edward Elgar.

in-text citation: (Swann, 2014)

\section{Articles in reference books}

Alatas, S. F. (2006). Islam and the Science of Economics in Abu Rabi', I.M. The Blackwell Companion to Contemporary Islamic Thought. USA: Willey-Blackwell (pp. 587-606).

in text citation: (Alatas, 2006)

\section{E-Book}

Hackett, Rosalind (2007). "Religous Dimentions of War and Peace: Introduction.” Dalam Gerrie ter Haar dan Yoshio Tsuruoka (Ed.), Religion and Society: An Agenda for the 21st Century (h. 3-6). Retrieved from http:// brill.nl.

in text citation: (Hackett, 2006)

\section{Master's thesis, from a commercial database}

McNieI, D. S. (2006). Meaning through narrative: A personal narrative discussing growing up with an alcoholic mother (Master's thesis). Available from ProQuest Dissertations and Theses database. (UMI No. 1434728)

in text citation: (Mc Niel, 2006)

\section{Doctoral dissertation, from an institutional database}

Adams, R. J. (1973). Building a foundation for evaluation of instruction in higher education and continuing education (Doctoral dissertation). Retrieved from http://www.ohiolink.edu/etd/

in text citation: (Adams, 1973) 


\section{Doctoral dissertation, from the web}

Bruckman, A. (1997). MOOSE Crossing: Construction, community, and learning in a networked virtual world for kids (Doctoral dissertation, Massachusetts Institute of Technology). Retrieved from http:/www-static. cc.gatech.edu/--asb/thesis/ in text citation: (Bruckman, 1997)

\section{Journal article with No DOI}

Bourkhis, K., and Nabi, M. S. (2013). Islamic and conventional banks' soundness during the 2007-2008 financial crisis. Journal Metrics, 22(2), 68-77.

in-text citation: (Bourkhis \& Nabi, 2013).

\section{Journal article with DOI}

Ichwan, M. (2012). The Local Politics Of Orthodoxy: The Majelis Ulama Indonesia in the Post-New Order Banten. Journal Of Indonesian Islam, 6(1), 166-194. doi:http://dx.doi.org/10.15642/JIIS.2012.6.1.166-194

In text citation : (Ichwan, 2012)

\section{Abstract as citation}

Hasan, N. (2012). Islamist Party, Electoral Politics And Da'wah Mobilization Among Youth : The Prosperous Justice Party (PKS) in Indonesia. Journal of Indonesian Islam, 6(1), 17-47. Abstract from http:// jiis.uinsby.ac.id/index.php/jiis/article/view/97

in text citation : (Hasan, 2012)

\section{Mass media article}

Sahal, Akhmad (2014, March 2). Kiai Sahal dan Realisme Fikih.Tempo Magazine, p. 120.

in text citation : (Sahal, 2014) 


\section{Research report}

Fisher, B. S., Cullen, F. T., \& Turner, M. G. (2000). The Sexual Victimization of College Women. Research Report.

in text citation : (Fisher, Cullen, Turner, 2000)

\section{Monograph}

Routray, Bibhu Prasad (2013), National Security Decision-Making in India (RSIS Monograph No. 27). Singapura: Rajaratnam School of International Studies.

in text citation : (Routray, 2013)

\section{Proceeding article}

Sudibyakto, Hizbaron, D.R., \& Jati, R (Ed.) (2009), Proceeding International Seminar Disaster Theory, Research and Policy. International seminar held by Sekolah Pascasarjana, Universitas Gajahmada, Yogyakarta, 8-9 Desember 2009.

in text citation : (sudibyakto and Jati, 2009)

\section{Paper conference/seminar/symposium}

Janutama, Herman Sinung (2011). "Kraton dan Hubungan Antar Agama." Paper presented in Seminar Kraton dan Panatagama held by Center for the Study of Islam and Social Transformation (CISForm), Yogyakarta, 17 November.

in text citation :(Janutama, 2011)

\section{Online article in web}

Shiva, (2006, February). Bioethics: A Third World Issue. Native-web. Diperoleh dari http://www.nativeweb.org/ pages/legal/shiva.html

in text citation : (Shiva, 2006) 


\section{Online research report}

Kessy, S. S. A., \& Urio, F M. (2006). The contribution of microfinance institutions to poverty reduction in Tanzania (Research Report No. 06.3). Retrieved from Research on Poverty Alleviation website: http://www. repoa.or.tz /documents_storage/Publications/Reports/06.3_Kessy_and_ Urio.pcif

in text citation : (kessy and urion, 2006)

\section{Holy book}

Qur an, $2(25)$

In text citation : (Q. al-Baqarah 2:25).

\section{Encyclopaedia}

Graycar, Adam (1992). Social Welfare Policy. Dalam Mary Hawkesworth dan Maurice Kogan (Ed.), Encyclopedia of Government and Politics (Vol. 1). London: Routledge.

in text citation : (Graycar, 1992)

\section{Interview}

Sultan Hamengkubuwono X (interview, 2011, April 19)

in text citation: (Hamengkubuwono, 2011)

\section{Documentary film}

Steijlen, Fridus (2008). A Day in the Life of Indonesia [documentary film, 58 minutes]. Leiden: KITLV Press.

in text citation : (Steijlen, 2008) 
Vol. 2 No. 1, January - April 2017 